\title{
A Cost Effectiveness Model for Comparing Various Circulation Systems
}

Thomas K. BURGESS: Washington State University Library

Two models for circulation systems costing are presented. Both the automated and the manual models are based on experience gained in the analysis of circulation services at Washington State University library. Validation tests for the model assumptions are devised and explained. Use of the models for cost effectiveness comparison and for cost prediction are discussed and examples are given showing their application.

\section{INTRODUCTION}

Many methods for analyzing cost effectiveness have been presented recently in the literature. ${ }^{1}$ One main difficulty with studies of effectiveness is in quantifying the benefits, or in the case of libraries, assigning values to the quantity or quality of the services offered., 3

One way to circumvent this difficulty is to compare the costs of different methods of providing the same services. Value assessment of the services is eliminated by keeping them constant as shown in most cost benefit studies. $^{1-6}$

This, of course, is not always possible when comparing manual library systems with mechanized systems. Library circulation systems, however, may fit this type of model with relative ease. For this reason, the models described below were developed to compare a manual with a mechanized system. They have the added advantage of allowing for the prediction of costs for either the manual or automated system based on certain circulation loads.

The utilization of the models is probably best understood by working through an application. Therefore, a description of these applications as performed at Washington State University library will be used. Assumptions based on practices peculiar to Washington State University are removed by the model through the use of the activities definitions for our library.

Washington State University library has been operating a mechanized circulation system since 1967. Based on past experience, the system has recently undergone major modifications to improve its capabilities. We consider it to be a highly efficient machine circulation system. Thus, cost 
effectiveness comparison with a similar manual operation can provide information on effectiveness of automated circulation systems in general as well as on the WSU implementation.

\section{MODEL CONSIDERATION}

To insure that the comparisons were fair and that biases were held to a minimum, mathematical models had to be established with rather rigid constraints. Validations of these models had to be devised to insure that extrapolations of the model results were meaningful.

Information about our manual system in operation prior to 1967 is sparse, as no analysis had been performed. It was decided that the manual model should, therefore, be a variant of the machine model, since our machine system includes a small manual system.

If the models are to be useful to others, they should make very few assumptions about circulation tasks. Therefore, the models should break out each specific task so costs can be accumulated. This also insures that only circulation tasks are counted. If total hours of staff assigned to circulation are used as the basic labor costs, their time at other library functions are included and would provide erroneous data. Using a breakdown by tasks will allow use of the model even if major changes occur in organizational or physical rearrangement of the circulation functions.

Twenty-three basic activities were identified that would cover all circulation functions of our library. A similar list should be prepared for each library to be modeled. ${ }^{7}$ Our list can be used as a guide. These functions and their definitions are listed in Appendix A. Fifteen functions represent activity for which both the quantity of the activities and the average time to perform it are required information for building the model. Of the nine remaining activities, eight require only the measurement of total performance time. The last activity, computer operations, was subdivided into three parts: computer charges, library equipment rental costs, and computer personnel costs. The computer personnel costs represent time donated by the Computer Center to keypunch, decollate and burst printouts, and prepare and schedule jobs. These personnel costs are a part of the machine system and are not reflected otherwise in the computer charges. These three charges are summed and used as a single dollar figure in the model. In our machine system as in many other circulation systems it is impossible to split our computer cost for each circulation subfunction because we use integrated data bases which are charged as a single storage rental cost and not split up among the various programs.

The collection of data for this study could have resulted in a sizeable effort and could have unduly biased the data which were to be collected. ${ }^{8,8}$ For example, circulation clerks might have taken as much time to measure the circulation transactions as the circulation transactions themselves required. Therefore, we requested supervisors to estimate the time necessary for these tasks, the number of transactions performed, and the per- 
centage of staff and student hours used. These data were developed monthly for a three month period during the middle portion of a semester. Validation of these estimates to insure their reasonability was accomplished by comparing the total time expended in circulation as reported in the collected data with the total time assigned to circulation activities as reported in the payroll records (the usual manner of estimating costs)..$^{10} \mathrm{~A}$ surprisingly high degree of correlation was found primarily due to the fact that few of our circulation staff members have responsibilities outside of circulation.

The payroll data also had to be adjusted to reflect actual hours used in circulation functions. A 25 percent figure was used: to reflect holidays and leaves-8.4-10 percent; coffeebreaks-8-12 percent; sickness-2 percent; tardiness and work slumps-3 percent; and miscellaneous-3 percent, for regular staff. By the same method 15 percent was determined for student help. The difference in total hours between the two samples was less than 5 percent (Appendix B, Table 5 ).

The study data were collected from five separate organizational areas (three circulation desks, Technical Service Division, and the Library Administrative Office) which are reasonably independent of each other; the monthly variation in activities reported by the various units was also closely correlated. For example, the percent increase in checkouts for a month was approximately the same at all three circulation desks.

\section{MODEL CALCULATIONS-AUTOMATED SYSTEM}

Monthly totals were averaged for each activity's transaction time, number of transactions, and percentage of effort allocated to staff, or student labor (Appendix B, Tables 1, 2, and 3). Average hourly wages were developed separately for student (part-time help) and staff based on salaries of personnel allocated to circulation. The total hours and salaries were then calculated for staff and student help for each activity. The following example shows the formulas used in calculating some of the entries in the tables:

\section{A1 Manual Checkout}

Transactions $\left(\mathrm{Al}_{\mathrm{T}}\right)$ times transaction time $\left(\mathrm{Al}_{\mathrm{TT}}\right)$ equals total time expended $\left(\mathrm{AI}_{\mathrm{TE}}\right)$ adjusted to hours

Total part-time help in hours $\left(A 1_{\text {PTH }}\right)$ equals $\left(A 1_{T E}\right)$ times the percentage of student effort ( $\left.\mathrm{Al}_{\mathrm{PPTH}}\right)$

Total staff hours $\left(A I_{\mathrm{S}}\right)$ equals $\left(A 1_{\mathrm{TE}}\right)$ times the percentage of staff help $\left(\mathrm{Al}_{\mathrm{PS}}\right)$

Total salaries $\left(A I_{T S}\right)$ equals $\left(A l_{\mathrm{PTH}}\right)$ times student rate $\left(\mathrm{R}_{\mathrm{PTH}}\right)$ plus $\left(A l_{\mathbb{S}}\right)$ times staff rate $\left(\mathrm{R}_{\mathbb{S}}\right)$ 
Total staff hours $\mathrm{X}_{\mathrm{S}}=\mathrm{X}_{\mathrm{TE}} \cdot \mathrm{X}_{\mathrm{PS}}$

Total salaries $\mathrm{X}_{\mathrm{TS}}=\mathrm{X}_{\mathrm{S}} \cdot \mathrm{R}_{\mathrm{B}}+\mathrm{X}_{\mathrm{PTH}} \cdot \mathrm{R}_{\mathrm{PTH}}$

All other activities were calculated in the same manner as shown above. Personnel hours used were totaled and multiplied by the hourly rates. The salary totals and the computer costs were then added together to get the total system cost per month. (Appendix B, Table 6)

Total salary cost $=1.15 \underset{\mathrm{i}=\mathrm{A}}{\mathrm{\Sigma}} \mathrm{i}_{\mathrm{PTH}} \cdot \mathrm{R}_{\mathrm{PTH}}+1.25 \underset{\mathrm{i}=\mathrm{A}}{\mathrm{V}} \mathrm{i}_{\mathrm{g}} \cdot \mathbf{R}_{\mathrm{S}}$

Figure 1 represents curves of monthly cost vs. monthly circulation. The automated system curve was determined from the initial model plotted point, and from extrapolations to other plotted points which were computed based on the following factors: A 25 percent increase or decrease in circulation will result in a 5 percent increase or decrease in computer costs. This estimate results from analyzing the computer processes. The bulk of the computer cost results from sorting and other total file processes which are reasonably insensitive to changes in volume of updating.

A factor of 25 percent change in circulation results in a 30 percent change in personnel costs. The 5 percent differential may be conservative, but results from the need for additional supervisory support with its higher salary for each additional operational position added.

Using the above factors, several additional points were predicted and plotted and the automated system curve was drawn to fit these points (Appendix B, Table 7). Validation of these factors was determined by using budget information and circulation data available from the year 1968 (Appendix B, Table 8). These data were used to establish a point on the graph. The 1968 costs were compared to the predicted cost as shown by the curve for the circulation volume in 1968. This provided a cost differential which was within 1 percent of the curve predicted costs (Figure 1).

These data were adjusted to reflect annual circulation hours used in circulation in 1971.

\section{MODEL CALCULATIONS-MANUAL SYSTEM}

The manual model was a modification of the automated model. Obviously no machine costs were incurred, but costs for filing and retrieving cards from large tub files of book cards of items in circulation must be added to each check-out or check-in procedure as well as to snags, holds, and other categories.

Since some loaned materials are not included in our automated system, a small manual circulation operation runs parallel to the automated system and was included in the automated study. This small manual system served as the base activity for the manual model in the study. 
Retrieval time from a card tub file is dependent on the number of the cards in the file. The tub file size is approximately equal to the size of the computer's circulation file. Sample filing times were made on a catalog card file of comparable size. The results were an average of 40 seconds per item on timings of single records and of batches of alphabetized records to be filed.

This figure was then used to extend the average time of the appropriate activities in the parallel manual systems data (Activities A1, B, Il, K, M, and Q). Following the calculation method used in our automated system, data were developed from the 1971 circulation data and a curve was drawn for the manual system (Appendix C and Appendix B, Table 7 and Figure 1). Validation of this curve by budget information available from 1967 shows that the difference in the predicted cost from actual cost was less than 2 percent (Appendix C, Table 5). This represents a significant correlation and validates the entire manual model.

\section{GENERALIZED USE OF THE MODELS}

As has been shown by the example of its use at WSU, the models provide for two functions: cost comparison of automated and manual circulation systems at the same levels of book circulation, and prediction of cost in either a manual or automated system at different levels of circulation.

Of course, combinations of these models may be made, such as: at what circulation levels are costs of both models equal? Or, what will my costs

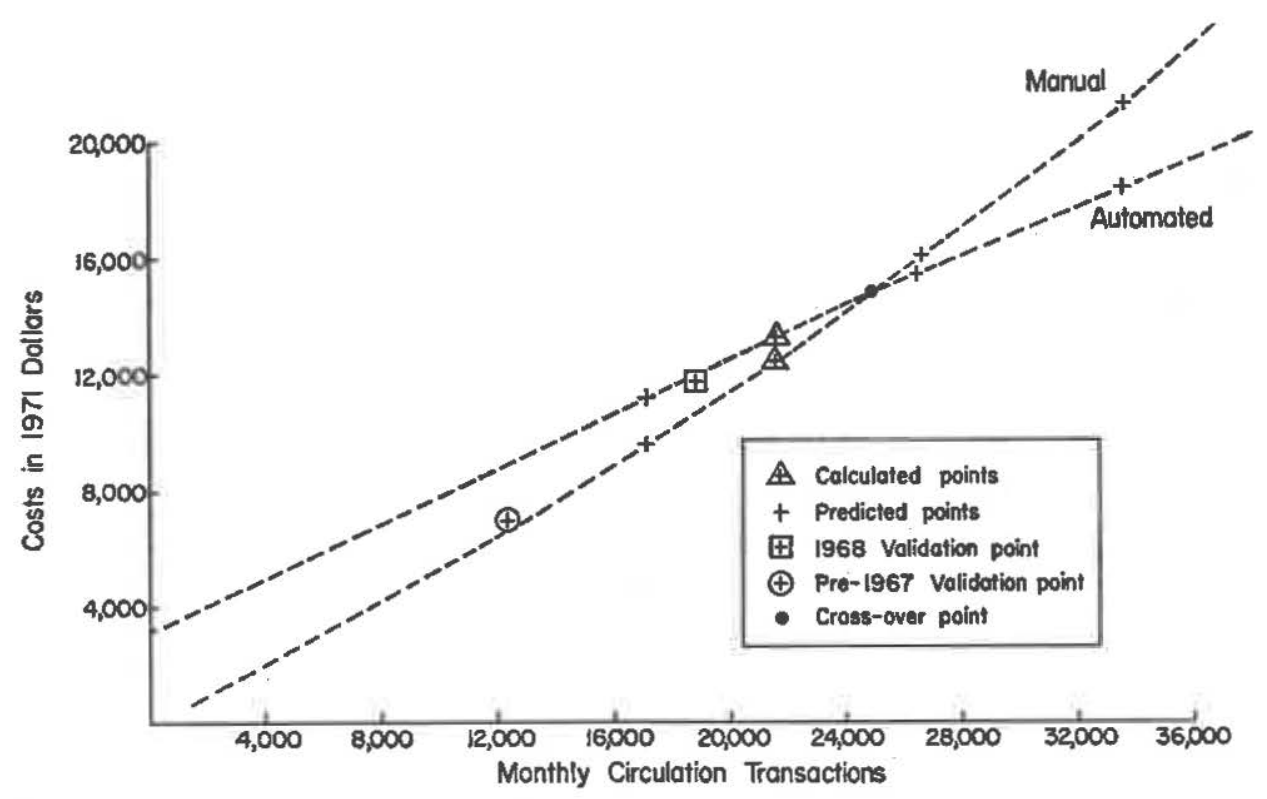

Fig. 1. Circulation Cost Curves 
be for both systems if my circulation increases by 10 percent? To use these models the following steps will provide a guideline:

A. Automated Model

1. Determine activities such as those outlined in Appendix A.

2. Collect data and estimates for a reasonable time period.

3. Determine costs using average local salary rates and formulas one through eight (p. 77-78).

4. Predict costs at various circulation levels.

B. Manual Model

1. Determine activities such as those outlined in Appendix A and modified for manual system.

2. Collect data and estimates for a reasonable time period.

3. Determine costs using average local salary rates and formulas one through eight (p. 77-78).

4. Predict costs at various circulation levels.

To make an effectiveness comparison, draw curves for both the manual and automated systems.

\section{CONCLUSIONS}

Will these models hold for other libraries, since many of the model factors were based on WSU data? The validations of the curves for 1968 and for 1967 provide the key to that question. First, the 1968 automated circulation system was not the same as the 1971 system. The system was extensively rewritten to (a) reduce computer costs and (b) handle new terminal equipment which was more expensive, offsetting total cost reduction but allowing for increased terminal capabilities. The correlation between actual costs in 1968 and predicted costs from 1971 data was extremely close.

Secondly, the real 1967 manual costs were closely correlated with the predicted manual costs derived from a hypothetical 1971 manual system. Therefore, the models reasonably represent generalized circulation activities.

The models described above can be used with decentralized or centralized circulation services or for comparisons between various combinations of circulation services, automated or otherwise, because measurements are based on circulation tasks and not on the total assignment of personnel. Timing estimates may vary between libraries and should be included as part of the data collection.

\section{APPENDIX A}

\section{Activity Definitions for Circulation Cost Study}

This listing generally represents groups of related activities. Grouping represents those clusters of activities which supervisors are reasonably able to identify and relate 
to estimates. This differs from Bellomy's approach in the University of California Study. 9

\section{A. Check-Out (1-Manual or 2-Machine).}

Those activities directly involved with the actual physical check-out of materials (manual transactions to be collected separately. Random estimates of manual physical files can be used to determine monthly totals and daily averages. Random measurements of time required to perform these functions should also be made to determine the average transaction times.)

B. Location of Materials.

Those activities to determine if a check-out, referral to other divisional or branch libraries, hold-recall, or snag function must be performed (again random estimates should be made to determine averages for number of activities and time consumed). This should include first shelf check.

C. Hold Form Preparation.

This activity is confined to the filling out of the Hold form. (Random estimates of total transactions and time should be made. Estimates on percent of student and staff efforts should be included).

D. Snag Form Preparation.

This activity is confined to the filling out of the Snag form. (Estimates should be made the same as in item C).

E. Photocopy Requests.

This activity is confined to the preparation and checking of the Photocopy request. (Estimates follow the procedure of item C).

F. Interlibrary Loan Requests.

That action necessary to prepare and check the Interlibrary Loan form. (Estimates should be made as in item C).

G. Recall.

Those activities necessary to prepare recall notices and forward them to the user. (Estimates should be made as in item C).

H. Snag Shelving Check.

Periodic shelving checks for snags. (Estimates should be made as in item C).

I. Check-In Processing (1-Manual or 2-Machine).

Those activities necessary to check in a book and prepare it for the shelving crew.

This will include check on the Hold-Snag, minor repair, and sequencing. (Separate estimates for both manual and machine process should be made as indicated in item A).

J. Notification.

The activities necessary to prepare and forward notification to patron of hold item availability. (Estimates should be made as in item C).

K. Overdue Preparation (Manual only).

Those activities necessary to prepare overdue notices. (Estimates should follow the procedure in item $\mathrm{C}$ ).

L. Overdue Notice Disposition.

Those activities required to handle overdue notices brought to the library's attention by the user with or without the material involved, or those returned to library due to misaddressing, or processing of University of Idaho patron notices. (Estimates should be made as in item $C$ ).

M. Fine Notice Preparation (Manual only).

Those activities necessary to prepare fine notices. (Estimates should be made as in item $\mathrm{C}$ ).

N. Fine Notice Disposition (Manual only).

Those activities required to handle fine notices brought to the library's attention 
by the user with or without the material involved, or those returned to library due to misaddressing, or processing of University of Idaho patron notices. Maximum fine activities are excluded. (Estimates should be made as in item C).

O. Replacement Costs Determination.

Those activities required to determine the cost of replacement and preparation and forwarding of this information. (Estimates should be made as in item C).

P. Maximum Fine Disposition.

Those activities required to handle maximum fines or lost books brought to the library's attention by the user. Include misaddressed notices and University of Idaho patron notices. (Estimates should be made as in item C).

Q. Reporting Fines.

Those manual activities necessary to report unpaid fines to the controller's office. (Estimates should be made as in item $\mathrm{C}$ ).

R. Shelf Reading.

That activity required to insure materials are properly sequenced in the stacks.

(Estimates should be made as in item C).

S. Collecting Room Materials.

Those activities required to collect and reshelve materials left on tables, stands, etc., in the division. (Estimates should be made as in item $\mathrm{C}$ ).

T. Supervising and Training.

Includes activities required to train and supervise all personnel assigned to circulation. Total hours.

U. Shelving.

This process includes pick-up of materials from book drops and the sorting and physical replacement on the shelves. Total hours.

V. Miscellaneous.

Those additional activities which the division feels should be included as a circulation function. Report each activity separately including a definition of the task.

W. Computer Costs and Equipment Rental.

Monthly billing for computing, equipment rental, and FTE assigned from schedule and control section.

\section{APPENDIX B}

\section{Automated Circulation Data by Function Groups}

\section{Circulation Control Grouping}

This section covers data recording, file maintenance, and retrieval. It includes activities A,I,T,W as defined in Appendix A.

Table 1. Check-out and Check-in of Materials

\begin{tabular}{|c|c|c|c|c|c|c|c|c|}
\hline \multirow{4}{*}{ Activity } & \multicolumn{3}{|c|}{ Average Monthly Figure } & \multicolumn{2}{|c|}{$\begin{array}{l}\text { \% of Activity } \\
\text { Performed by }\end{array}$} & \multirow{3}{*}{\multicolumn{2}{|c|}{ Dollars }} & \multirow{4}{*}{$\begin{array}{c}\text { Total } \\
\text { Dollars }\end{array}$} \\
\hline & \multirow{3}{*}{$\begin{array}{c}\text { Number of } \\
\text { Trans- } \\
\text { actions }(T)\end{array}$} & \multirow{3}{*}{$\begin{array}{c}\text { Trans- } \\
\text { action } \\
\text { Time }(T T) \\
\text { Trans- } \\
\text { action }\end{array}$} & \multirow{3}{*}{$\begin{array}{c}\text { Total time } \\
\text { Expended } \\
\text { (TE) } \\
\text { Hours }\end{array}$} & \multirow{3}{*}{$\begin{array}{l}\text { Full- } \\
\text { time } \\
\text { Staff }\end{array}$} & \multirow{3}{*}{$\begin{array}{l}\text { Part- } \\
\text { time } \\
\text { Staff }\end{array}$} & & & \\
\hline & & & & & & & & \\
\hline & & & & & & $\mathrm{S}$ & & \\
\hline Al & 4095 & $45 \mathrm{sec}$. & 51.19 & 16 & 84 & 19.73 & 70.08 & 89.79 \\
\hline A2 & 15612 & $11 \mathrm{sec}$. & 47.70 & 10 & 90 & 11.69 & 69.97 & 81.46 \\
\hline I1 & 4090 & $46 \mathrm{sec}$. & 52.26 & 12 & 88 & 15.11 & 74.94 & 90.05 \\
\hline I2 & 15396 & $13 \mathrm{sec}$. & 55.60 & 10 & 90 & 13.39 & 81.56 & 94.95 \\
\hline \multirow[t]{2}{*}{$\mathrm{T}$} & - & - & 453.00 & 100 & - & 1091.73 & - & 1091.73 \\
\hline & & & 659.75 & & & & & 1447.98 \\
\hline
\end{tabular}


Table 2. Basic Processing

Activity $W$

Hours

Library Dollars

Total Dollars

Library Rental Equipment for Circulation

$1273.15 / \mathrm{mo}$

Average Computing Cost

$4942.83 / \mathrm{mo}$

Book Card Preparation

Systems*

Technical Service Division

$80 \mathrm{hr}$. (full-time)

$80 \mathrm{hr}$. (full-time) $\quad 192.00$

192.00

195 hr. (part-time) 263.25

192.00

$21.4 \mathrm{hr}$. (full-time) $\quad 85.60$

317.85

85.60

Maintenance

1036.15

8451.91

"Systems personnel are staffed by OSS\&D primarily with some library staff support.

II. Retrieving Materials Grouping

This group consists of Activities B, C,D,E,F,G,H,J,K,L,R,S,U,V.

Table 3. Average Monthly Data

\begin{tabular}{|c|c|c|c|c|c|c|c|c|}
\hline \multirow[b]{2}{*}{ Activity } & \multirow[b]{2}{*}{ Items } & \multirow{2}{*}{$\begin{array}{c}\text { Average } \\
\text { Time }\end{array}$} & \multirow{2}{*}{$\begin{array}{l}\text { Total } \\
\text { Hours }\end{array}$} & \multicolumn{2}{|c|}{$\begin{array}{l}\text { \%of } \\
\text { Time by }\end{array}$} & \multicolumn{2}{|c|}{$\begin{array}{l}\text { Library } \\
\text { Dollars }\end{array}$} & \multirow{2}{*}{$\begin{array}{c}\text { Total } \\
\text { Univ. } \\
\text { Dollars }\end{array}$} \\
\hline & & & & S & $P T H$ & S & PTH & \\
\hline B & 7142 & $2.2 \mathrm{~min}$. & 261.9 & 20 & 80 & 126.23 & 341.51 & 467.74 \\
\hline C & 1237 & $3.0 \mathrm{~min}$. & 61.9 & 23 & 77 & 34.29 & 77.68 & 111.97 \\
\hline $\mathrm{D}$ & 351 & $3.5 \mathrm{~min}$. & 20.47 & 30 & 70 & 14.79 & 23.34 & 38.13 \\
\hline $\mathrm{E}$ & 94 & $6.45 \mathrm{~min}$. & 10.1 & 76 & 24 & 18.48 & 3.93 & 22.41 \\
\hline F & 22 & $2.0 \mathrm{~min}$. & .7 & 100 & - & 1.68 & $\ldots$ & 1.68 \\
\hline$G$ & 1252 & $4.36 \mathrm{~min}$. & 91.00 & 75 & 25 & 164.48 & 37.08 & 201.56 \\
\hline $\mathrm{H}$ & 701 & $3.2 \mathrm{~min}$. & 37.4 & 50 & 50 & 45.06 & 30.47 & 75.53 \\
\hline $\mathrm{J}$ & 1250 & $3.5 \mathrm{~min}$. & 72.9 & 75 & 25 & 131.75 & 29,69 & 161.44 \\
\hline $\mathrm{K}$ & 517 & $5.0 \mathrm{~min}$. & 43.08 & 20 & 80 & 20.75 & 56.16 & 76.91 \\
\hline $\mathrm{L}$ & 40 & $4.0 \mathrm{~min}$. & 2.66 & 95 & 5 & 6.07 & .20 & 6.27 \\
\hline $\mathbf{R}$ & $\ldots$ & - & 154 & 5 & 95 & 18.55 & 239.56 & 257.01 \\
\hline S & - & - & 205 & 25 & 75 & 123.51 & 250.61 & 374.12 \\
\hline $\mathrm{U}$ & - & - & 45 & 95 & 5 & 103.02 & 3.66 & 106.68 \\
\hline $\mathrm{V}$ & - & - & 746 & 20 & 80 & 359.57 & 973.88 & 1332.35 \\
\hline Total & & & 1752.11 & & & & & 3233.80 \\
\hline
\end{tabular}

III. Fine Process Grouping

This group includes Activity $\mathrm{M}, \mathrm{N}, \mathrm{O}, \mathrm{P}, \mathrm{Q}$.

Table 4. Fine Processing

\begin{tabular}{|c|c|c|c|c|c|c|c|c|}
\hline \multirow[b]{2}{*}{ Activity } & \multirow[b]{2}{*}{ Number } & \multirow{2}{*}{$\begin{array}{c}\text { Average } \\
\text { Time }\end{array}$} & \multirow{2}{*}{$\begin{array}{l}\text { Total } \\
\text { Time }\end{array}$} & & \multicolumn{2}{|c|}{$\begin{array}{l}\text { Library } \\
\text { Dollars }\end{array}$} & \multirow{2}{*}{$\begin{array}{l}\text { Total } \\
\text { Univ. } \\
\text { Dollars }\end{array}$} \\
\hline & & & & $S$ & $P T H$ & $S$ & PTH & \\
\hline M & 350 & $2.5 \mathrm{~min}$. & 14.58 & 95 & 5 & 33.37 & 1.18 & 34.55 \\
\hline $\mathrm{N}$ & 18 & $4.0 \mathrm{~min}$. & 1.2 & 100 & - & 2.89 & - & 2.89 \\
\hline 0 & 90 & $4.0 \mathrm{~min}$. & 6.0 & 95 & 5 & 13.73 & .48 & 14.21 \\
\hline $\mathrm{P}$ & - & - & 41.2 & 100 & - & 99.29 & - & $99.29^{*}$ \\
\hline $\mathrm{Q}$ & - & - & 33.0 & 100 & - & 79.53 & - & 79.53 \\
\hline Total & & & 95.98 & & & & & 230.47 \\
\hline
\end{tabular}

* Was supported in part by the Computing Center 


\section{Journal of Library Automation Vol. 6/2 June 1973}

Table 5. Validation of 1971 Data Collection Procedures

Part-time hours used as collected

1644.88

Full-time hours used as collected

1343.58

Total hours used

2988.46

Total hours reported in Payroll divided by 1.25 to get actual hours used in circulation tasks ${ }^{*}$

Difference-5\%

3146.04

- Factors used to compensate for leaves, coffeebreaks, etc.

Table 6. Summary Data

$25 \% \mathrm{Vol}$.

Increase

Total Completed Circulation Avg. 1971 Monthly Dollars

Hours

Cost per Circulation

Time per Circulation

Average Daily Circulation

24,496

$15,393.06$

$\$ 13,039.23$

$3,735.57$

$\$$

9 min. 9 sec.

653 items

816

Table 7. Model Cost Curve Calculations

\begin{tabular}{|c|c|c|c|c|}
\hline \multicolumn{5}{|l|}{ Manual System } \\
\hline Number of Circulations & 17,200 & $21,500^{*}$ & 26,875 & 33,594 \\
\hline Labor & $\$ 9,629.68$ & $\$ 12,518.59$ & $\$ 16,274.16$ & $\$ 21,156.40$ \\
\hline \multicolumn{5}{|l|}{ Automated System } \\
\hline Number of Circulations & 17,200 & $21,500^{*}$ & 26,875 & 33,594 \\
\hline Machine & $\$ 5,919.98$ & $\$ 6,215.98$ & $\$ 6,526.77$ & $\$ 6,853.10$ \\
\hline Labor & $5,248.65$ & $6,823.25$ & $8,870.21$ & $11,531.27$ \\
\hline Total & $\$ 11,168.63$ & $\$ 13,039.23$ & $\$ 15,396.98$ & $\$ 18,384.37$ \\
\hline \multicolumn{5}{|c|}{ Formulas for determining projected points on the curve } \\
\hline \multirow{2}{*}{ Circulation } & $\mathrm{X}$ & \multirow{2}{*}{$\mathrm{X}$} & \multirow{2}{*}{$1.25 \mathrm{X}$} & \multirow{2}{*}{$1.56 \mathrm{X}$} \\
\hline & 1.25 & & & \\
\hline Labor & $\frac{A}{1.30}$ & $\mathrm{X}$ & $1.30 \mathrm{X}$ & $1.69 \mathrm{X}$ \\
\hline Equipment & $\frac{X}{1.05}$ & $\mathrm{X}$ & $1.05 \mathrm{X}$ & $1.10 \mathrm{X}$ \\
\hline
\end{tabular}

- Adjusted to remove spring slump bias by averaging fall and spring figures

Table 8. Curve Validation

$\begin{array}{lr}1968 \text { Automated System } & \\ \text { Part-time hours used } & \$ 1,606.71 \\ \text { Full-time hours used } & 1,285.38 \\ \text { Adjusted total dollars } & 5,748.83 \\ \text { Average computer costs } & 6,056.24 \\ \text { Total costs } & 11,805.07 \\ \text { Circulation } & 590 \\ \text { Model costs at } 590 \text { circulation } & 11,990 \\ \text { Difference } & 1 \%\end{array}$

- Reported in 1968 payroll

* Adjusted to 1971 dollars and hours devoted to circulation activities 


\section{APPENDIX C}

I. Circulation Control Grouping

Manual Circulation System Extrapolation

This section covers data recording, file maintenance, and retrieval. It includes Activity A,I,T, as defined in Appendix A.

Table 1. Check-out and Check-in Materials

\begin{tabular}{|c|c|c|c|c|c|c|c|c|}
\hline \multirow{3}{*}{ Activity } & \multirow{3}{*}{$\begin{array}{l}\text { Number of } \\
\text { Transactions }\end{array}$} & \multirow{3}{*}{$\begin{array}{c}\text { Time for each } \\
\text { Transaction }\end{array}$} & \multirow{3}{*}{$\begin{array}{l}\text { Total } \\
\text { Hours }\end{array}$} & \multicolumn{2}{|c|}{$\begin{array}{l}\text { \% of Activity } \\
\text { Performed by }\end{array}$} & & & \multirow{3}{*}{$\begin{array}{l}\text { Total } \\
\text { Univ. } \\
\text { Dollars }\end{array}$} \\
\hline & & & & $\begin{array}{l}\text { Full- } \\
\text { time }\end{array}$ & $\begin{array}{l}\text { Part- } \\
\text { time }\end{array}$ & \multicolumn{2}{|c|}{$\begin{array}{l}\text { Library } \\
\text { Dollars }\end{array}$} & \\
\hline & & & & Staff & Help & $F T$ & PTH & \\
\hline A & 22500 & $1.25 \mathrm{~min}$. & 468.75 & 16 & 84 & 180.75 & 649.68 & 830.43 \\
\hline$I$ & 20500 & $1.25 \mathrm{~min}$. & 427.08 & 12 & 88 & 121.53 & 610.19 & 731.72 \\
\hline T & - & - & 800 & 100 & - & 1928.00 & - & 1928.00 \\
\hline Total & & & 1695.83 & & & & & 3490.15 \\
\hline
\end{tabular}

II. Retrieving Materials Grouping

This group consists of Activities B, C,D,E,F,G,H,J,K,L,R,S,U,V.

Table 2. Average Monthly Data

\begin{tabular}{|c|c|c|c|c|c|c|c|c|}
\hline \multirow[b]{2}{*}{ Activity } & \multirow[b]{2}{*}{ Items } & \multirow{2}{*}{$\begin{array}{l}\text { Average } \\
\text { Time }\end{array}$} & \multirow{2}{*}{$\begin{array}{l}\text { Total } \\
\text { Hours }\end{array}$} & \multicolumn{2}{|c|}{$\begin{array}{c}\% \text { of } \\
\text { Time by }\end{array}$} & \multicolumn{2}{|c|}{$\begin{array}{l}\text { Library } \\
\text { Dollars }\end{array}$} & \multirow{2}{*}{$\begin{array}{c}\text { Total } \\
\text { Univ. } \\
\text { Dollars }\end{array}$} \\
\hline & & & & $S$ & $P T H$ & S & PTH & \\
\hline B & 35750 & $3.0 \mathrm{~min}$. & 1787.5 & 20 & 80 & 861.57 & 2359.50 & 3221.07 \\
\hline C & 1245 & 3.0 min. & 62.25 & 23 & 77 & 34.48 & 79.08 & 113.56 \\
\hline D & 360 & 3.5 min. & 21.0 & 30 & 70 & 15.18 & 24.25 & 39.43 \\
\hline $\mathrm{E}$ & 95 & $6.45 \mathrm{~min}$. & 10.2 & 76 & 24 & 18.67 & 4.04 & 22.71 \\
\hline $\mathrm{F}$ & 25 & $2.0 \mathrm{~min}$. & .83 & 100 & - & 2.00 & - & 2.00 \\
\hline $\mathrm{G}$ & 1255 & $4.36 \mathrm{~min}$. & 91.19 & 75 & 25 & 164.81 & 37.60 & 202.41 \\
\hline$H$ & 875 & $3.2 \mathrm{~min}$. & 46.67 & 50 & 50 & 56.22 & 38.48 & 94.70 \\
\hline J & 1260 & $3.5 \mathrm{~min}$. & 73.5 & 75 & 25 & 132,83 & 30.30 & 163.13 \\
\hline $\mathrm{K}$ & 4945 & 5.5 min. & 453.29 & 20 & 80 & 218.46 & 598.33 & 816.79 \\
\hline L & 55 & $4.0 \mathrm{~min}$. & 3.67 & 95 & 5 & 8.38 & .29 & 8.67 \\
\hline $\bar{R}$ & - & - & 155 & 5 & 95 & 18.67 & 242.96 & 261.63 \\
\hline$S$ & - & - & 205 & 25 & 75 & 123.51 & 253.68 & 377,19 \\
\hline $\mathrm{U}$ & - & - & 45 & 95 & 5 & 103.02 & 3.71 & 106.73 \\
\hline V & - & - & 746 & 20 & 80 & 359.57 & 984.71 & 1344.28 \\
\hline Total & & & 3701.10 & & & & & 6774.30 \\
\hline
\end{tabular}

III. Fine Process Grouping

This group includes Activities $\mathrm{M}, \mathrm{N}, \mathrm{O}, \mathrm{P}, \mathrm{Q}$.

Table 3. Fine Processing

\begin{tabular}{|c|c|c|c|c|c|c|c|c|}
\hline Activity & Number & $\begin{array}{c}\text { Average } \\
\text { Time }\end{array}$ & $\begin{array}{l}\text { Total } \\
\text { Time }\end{array}$ & $F T$ & $P T$ & $F T$ & $P T$ & $\begin{array}{c}\text { Total } \\
\text { Univ. } \\
\text { Dollars }\end{array}$ \\
\hline M & 2795 & $3.2 \mathrm{~min}$. & 149.06 & 75 & 25 & 269.41 & 69.39 & 330.80 \\
\hline $\mathrm{N}$ & 20 & $4.0 \mathrm{~min}$. & 1.33 & 100 & - & 3,20 & - & 3.20 \\
\hline 0 & 125 & $4.0 \mathrm{~min}$. & 8.33 & 95 & 5 & 19.06 & .66 & 19.72 \\
\hline $\mathrm{P}$ & - & - & 41.2 & 100 & - & 99.29 & - & 99.29 \\
\hline$Q$ & - & - & 45. & 100 & - & 108.45 & - & 108.45 \\
\hline Total & & & 244.92 & & & & & 561.46 \\
\hline
\end{tabular}


Table 4. Summary Data

$25 \%$ Vol.

Total

Increase

Total Completed Circulation

Adjusted Dollars

26,875

Hours

Cost per Circulation

Time per Circulation

Average Daily Circulation

Part-time hours used

Full-time hours used

21,500
$\$ 12,518.59$
$5,910.02$
$\$ \quad .58$
16 min. $23 \mathrm{sec}$
717 Items
$3,774.78$
$2,135.24$

Table 5. Model Validation

Pre-1967 Manual System

Part-time hours used ${ }^{\circ}$

Full-time hours used ${ }^{\circ}$

2485

1574

$\$ 6,600$

Circulation

Model value at 415 circulation from Figure 1

Difference

$2 \%$

\footnotetext{
* from 1967 payroll data

*a adjusted to 1971 dollars and to hours devoted to circulation
}

\section{REFERENCES}

1. M. G. Kendall, ed., Cost Benefit Analysis, a symposium held in The Hague in July 1969 under the aegis of the NATO Scientific Affairs Committee (New York: American Elsevier Publishing Co., 1971).

2. E. J. Mishan, Cost Benefit Analysis: An Introduction (New York: Praeger, 1971).

3. U. V. Novozhilov, Problems of Cost Benefit Analysis in Optimal Planning (White Plains, N.Y.: International Artist Sciences Press, Inc., 1970).

4. L. Hargrove and K. H. Stirling, California State Library; Processing Center Designs and Specifications. Vol. V: Cost Analysis, University of California Institute of Library Research (Berkeley: Institute of Library Research, 1970).

5. J. A. Raffel and R. Shishko, Systematic Analysis of University Libraries, an Application of Cost Benefit Analysis to the MIT Libraries (Cambridge, Mass.: MIT Press, 1969).

6. Claire K. Schultz, "Cost Effectiveness as a Guide in Developing Indexing Rules." Information Storage and Retrieval 6:335-40 (Oct. 1970).

7. Joseph Becker and Robert A. Hayes, Handbook of Data Processing for Libraries (New York: Wiley, 1970).

8. Watson Pierce, "Work Measurement in Public Libraries; a Report to the Director of the Public Library Inquiry" (New York: Social Science Research Council, 1949).

9. Fred Bellomy, Private Correspondence, May 1971.

10. R. M. Dougherty and F. J. Heinritz, Scientific Management of Library Operations (New York: Scarecrow Press, Inc., 1966). 